\title{
Psicooncología
}

ISSN: 1696-7240

\section{Orthotanasia and dignified death in cancer patients: The perception of health professionals}

\author{
Hélen Rimet Alves de Almeida ${ }^{1}$; Cynthia Freitas de Melo,"*
}

Recibido: 11 de julio de 2018 / Aceptado: 20 de agosto de 2018

\begin{abstract}
Objective: to analyze the perception about dignified death and orthothanasia in the view of health professionals who provide curative and palliative care in oncology. Method: this is a research with exploratory, qualitative approach. Saturation criteria included the participation of eight health professionals from the Cancer Institute of Ceará, Brazil: a physician, a nurse, a social worker and a psychologist of the palliative care team, and an oncologist, a nurse, a social worker and a psychologist of the curative care team. Three instruments were used: semi-structured interview; Free Word Association Test (WAT) with "cancer" and "orthothanasia" as inductive stimulus; and a Photo Projection Test (PPT) using five images. A textual analysis was carried out using the Iramuteq software to analyze the interviews. For the analysis of the WAT, the frequencies of the words of each stimulus were counted; then they were submitted to the word reduction technique and understood through simple frequency analysis. For the analysis of the PPT, the frequencies were counted, followed by analysis of meanings. Results: cancer is perceived by professionals as synonymous with death, pain and suffering, and orthothanasia as a practice of care and affection. The importance of the transition from curative care to exclusive palliative care is evident when there is no prognosis of cure, so as to offer quality of death and pain relief. This process can be facilitated by the acceptance of death and participation on the part of the family. The family must also receive care. Conclusion: health professionals recognize the importance and challenges of orthothanasia.
\end{abstract}

Keywords: Health professionals; dignified death; orthothanasia.

\section{[es] Ortotanasia y muerte digna en pacientes con cáncer: La percepción de los profesionales de la salud}

Resumen: Objetivo: el presente artículo objetivó analizar la percepción sobre la muerte digna y la ortotanasia para los profesionales de salud de cuidado curativo y paliativo en oncología. Método: se realizó una investigación descriptiva y exploratoria de abordaje cualitativo. Se contó con la participación de ocho profesionales de salud del Instituto del Cáncer de Ceará, en Brasil: médico, enfermera, asistente social y psicóloga del equipo de cuidados paliativos, y médico oncólogo, enfermera, asistente social y psicóloga del equipo de cuidados curativos. Se utilizaron tres instrumentos: entrevista semiestructurada, Prueba de Asociación Libre de Palabras (TALP) y Prueba de Proyección sobre Fotos (TPF). Las entrevistas fueron analizadas a través del software Iramuteq. Para el análisis del TALP, las palabras de cada estímulo fueron analizadas y contabilizadas las frecuencias; a continuación, fueron sometidas a la técnica de reducción de palabras y comprendidas por medio de análisis simple de frecuencia. Para el

1 Hélen Rimet Alves de Almeida. University of Fortaleza, Ceará, Brazil.

E-mail: helen.rimet@gmail.com

2 Cynthia Freitas de Melo. University of Fortaleza, Ceará, Brazil.

E-mail: cf.melo@yahoo.com.br

* Dirección de correspondencia: Cynthia Melo. Av. Washington Soares, 1321, Sala N13. Bairro Edson Queiroz, CEP.60.811-341. Fortaleza-CE. Email: cf.melo@yahoo.com.br 
análisis del TPF, se contabilizaron las frecuencias, seguidas de sus análisis de significados. Resultados: los resultados muestran que el cáncer se percibe como sinónimo de muerte, dolor y sufrimiento; y ortotanasia como cuidado y afecto. Se evidencia la necesidad de la aceptación de la muerte y del cambio de enfoque de cuidado de pacientes en proceso de finitud, y que por medio de los cuidados paliativos es posible ofrecer calidad de muerte y alivio del dolor. Conclusión: se concluye que los profesionales de la salud reconocen la importancia y los desafíos de la ortotanasia.

Palabras clave: profesionales de la salud; muerte digna; ortotanasia.

Sumario. 1. Introduction 2. Method 2.1. Type of study 2.2. Participants 2.3. Instruments and Techniques 2.4. Ethical Procedures and Data Collection 3. Data analysis 4. Results A. Interviews with Professionals B. Free Word Association Test - WAT C. Photo Projection Test - PPT Source: Direct search data. D. Triangulation of Results 5. Discussion 6. Conclusion 7. References.

Cómo citar: Rimet Alves de Almeida H, Freitas de Melo C. Orthotanasia and dignified death in cancer patients: The perception of health professionals. Psicooncología 2019;16:143-160. Doi: 10.5209/ PSIC.61442.

\section{Introduction}

Caring for others is a practice that involves humanization and is present throughout the individual's development from birth to death, including all the resulting situations after finitude. It is concretized by the act of providing assistance to others, be it to individuals, families or the society, through an interpersonal, egalitarian relationship based on human values and scientific knowledge. Caring for sick people, in turn, involves methods of greater complexity than cure. In this case, actions that help to improve the human condition, the well-being and quality of life of the patient gain prominence. In this breadth and complexity, medical care, medical attention, professional care and health care represent distinct concepts ${ }^{(1,2)}$.

Caring and care relate to activities that require attention and feelings, affection, in which "care in act" occurs when there is an investment in favor of another person. Professional care is represented by cognitive behaviors derived from traditional culture, practices and processes aimed at restoring or preserving health during life or in the process of death. Health care, rather than a technical procedure, is an integral action focused on the understanding of health as the right that people have of being what they are in their singularities and differences, and with an incentive to the active participation of users/patients in their health processes, in an empowered manner, and with overlapping of light technologies. In this perspective, care is an essential practice, and it is not the prerogative of a single profession ${ }^{(3,4)}$.

In some contexts, health care can be difficult, especially in those involving patients in the process of end of life, due to the fragility of the individuals involved and the complexity of respect for the singularity and active participation of the patients/users. In addition, professionals who take care of these patients have to deal with a routine that forces them to self-reflexion on topics normally banned, such as death itself and their attitude before the binomial death and life. These professionals are led to meet the reality denied by a society that rejects and fears death and by a professional training backed up by the unique goal of saving lives. As a consequence, death may be seen by them as a professional failure, trivialized or denied, through magical expectations of recovery ${ }^{(5-6)}$. 
In addition to the individual difficulties intrinsic to any health professional, two other issues need attention: the psychological fragility of patients and the adverse working conditions in the hospital environment. In this context, patients and family members experience the breakdown of life and future plans and have to deal with denial of the reality of death. Moreover, severe challenges posed by poor infrastructure conditions, lack of materials and human resources in Brazilian hospitals, and problems with hospital management and the working network ${ }^{(7-8)}$.

In order to mitigate these difficulties present in the process of end of life, it is necessary to strengthen health professionals, patients and their families to recognize and accept the terminality of life, with the inclusion of quality of death. In order to do this, academic training and professional training needs to direct more investment on topics such as thanatology, bioethics, biolaw and psychology. In their practice, health professionals still need to feel supported by a close management, with the presence of an integrated interdisciplinary team. Patients and families need support, embracement, and a relationship of trust and transparency with professionals ${ }^{(9,10)}$.

Once these conditions are satisfied, in the face of the process of finitude of life, there is a need for decision making regarding the health and illness process, and the form of care invested. Such decision is permeated by the acceptance or denial of death before two practical possibilities of approach: dysthanasia and orthothanasia ${ }^{(9-11)}$.

The term "therapeutic obstinacy" (l'acharnement thérapeutique) or dysthanasia is defined as a practice that uses therapeutic processes whose effects are more harmful than the effects of the being cured, or that are useless, because healing is impossible and the expected benefit does not compensate the discomfort generated. It occurs when the treatment provided exceeds the expected prognosis, delaying the dying process and prolonging the agony and suffering of the patient ${ }^{(12,13)}$.

On the other hand, orthothanasia respects death in its natural course, without artificially prolonging the process of end of life and the suffering of the patient. This practice does not involve any type of criminal act because the purpose of the professional act that interrupts the therapeutic treatment, by consent of the patient or the family or by a medical decision, is to reduce the suffering of a patient who has no chance of cure. In the case of terminally ill patients, there is respect for their self-determination, free will and right to choose, aiming to prioritize the freedom and right of patient to have the control over their lives. There is no abandonment of the patient in this case, or lack of conduct (misthanasia). There is a care that does not seek to maintain and prolong life (or death), but seeks to alleviate the symptoms and offer a dignified death ${ }^{(14,15)}$.

When orthothanasia is chosen in the case of patients in the process of finitude, another form of care emerges as a protagonist. Curative care gives way to exclusive palliative care. Care is sought to prevent and relieve symptoms, offering dignity in the process of death. It is noteworthy that these two forms of care should not be mutually exclusive. Thus, ideally, it is recommended that palliative care be initiated since the beginning of a life threatening disease, in its diagnosis, along with other curative therapies - such as chemotherapy or radiotherapy. As the disease progresses or fails to respond to curative treatment, the palliative approach gradually gains space in a continuous and dynamic manner, according to the needs of each patient, until becomes the exclusive form of care, when care has the objective to provide quality of death and pain relief to the patient ${ }^{(16,17)}$.

This decision can be made through careful evaluation, using protocols or functional assessments, supported by objective parameters of the underlying disease, 
its predicted prognosis and diagnosis of terminality. It is necessary to identify, based on a follow-up of the evolutionary curve, the difficulties faced by the patients, the stages of the progress of their disease and the treatments that have already been performed, the current symptoms and discomforts, physical exams, prescription drugs, the decisions of the team and the impression corresponding to the evolution, besides the perspectives regarding the proposed treatment. At the end of the process, palliative care is indicated when survival is estimated for no more than six months or when there is an irreversible loss of quality of life ${ }^{(18)}$.

Nearly all jurisprudence and doctrine makers understand the practice of orthothanasia as a licit conduct. They see that the right to life is not violated because since that moment, besides the need to respect the patient's autonomy, death is imminent and inevitable. The practice does not offend the constitutional right to life because it does not anticipate death; it just allows it following its natural course, with dignity, guaranteeing all the medical assistance possible, with applications of all available therapeutics to ameliorate pain, based on respect and humanized care for the patients. This would limit unnecessary treatments that cannot lead to cure or reversion of the condition ${ }^{(19)}$.

The norms linked to orthothanasia are in agreement with the Plan of Humanization of the Health Services of the Unified Health System (SUS) in force in Brazil, with the World Medical Association and the United Nations Educational, Scientific and Cultural Organization and Culture, with the European Council and the European Court of Human Rights, as well as the legal system adopted in the United States, Canada, Mexico, United Kingdom, Belgium, Netherlands, Sweden, Switzerland, France, Italy and Uruguay ${ }^{(20)}$. They were reinforced in Brazil by resolution of federal councils of different professional health categories which directly or indirectly legitimize orthothanasia and organize the actions of professionals.

Supported by these resolutions, health professionasl must be guided by ethics, seeking to promote the comfort and well-being of the patients, respecting their will and dignity even in the final stage of life. At this stage, palliative care and the promotion of physical, psychological and spiritual well-being are paramount. The attitude of professional is very important for the patients to become aware of and they take ownership of this process and become subjects and protagonists. Regardless of the religious conception and before the inevitable end, human dignity must be a preponderant aspect in medical conducts. The practice of palliative care in order to alleviate suffering should not be understood as disrespect for religiosity or for the human condition, but a way of smoothing the passage from physical life to death ${ }^{(14-21)}$. This practice should be supported and encouraged by the organizations and councils of all professional categories that participate in interdisciplinary teams of patient care in the process of finitude such as physicians, nurses, social workers and psychologists, among others.

According to the Brazilian Federal Council of Medicine, from the moment the terminality of life is diagnosed, any extra treatment will be ineffective. In this case, the physician cannot be allowed to do everything to save the patient's life (principle of beneficence), if there is no such possibility, i.e. of saving this life. Thus, when the condition is irreversible, if it is the will of the patient and his family, the correct attitude would be not to use excessive and futile therapeutic care. The therapy would only cause aggression to the patient. In this phase, the principle of non-maleficence assumes a privileged position over the principle of beneficence, since no therapeutic measure will benefit the patient. In that case, the Council Resolution 1805/2006 
infers that in the terminal stage of serious or incurable diseases, the physician is allowed to limit or suspend treatments that prolong the life of patients, guaranteeing them the necessary care to alleviate the symptoms that cause suffering ${ }^{(22)}$.

Similarly, in its Resolution $n^{\circ} 311 / 2007$, the Code of Ethics of Nursing Professionals in Brazil states that "nursing professionals respect life, dignity and human rights in all dimensions", and in article 29, it prohibits nursing professionals from "promoting euthanasia or participating in practices aimed at anticipating the death of the client". This normative nursing diploma does not regulate issues linked to dysthanasia and orthothanasia. However, by affirming the need to respect the dignity of patients, it encourages the professional to recognize that providing a good death means to offer care with dignity and respect, promoting a terminality with comfort and without pain ${ }^{(23,24)}$. These guidelines are in agreement with the codes of ethics of social workers ${ }^{(25)}$ and Psychology ${ }^{(26)}$.

The possibilities for the praxis of different professionals in the health care of terminally ill patients through orthothanasia are recognized and regulated in Brazil through these documents. Such actions are predominantly recognized within institutional boundaries, especially hospitals. As another possibility, home care has been the focus of priority programs of the World Health Organization (WHO) since 1996. This care modality has been persistently chosen to meet the needs of individuals with chronic diseases who depend on others, and it is justified by values such as the importance of contact and proximity to family members and affectivity in the family core, as well as a supposed better quality of life of patients and, of course, a decreased cost with respect to hospital beds ${ }^{(27)}$.

Thus, there is an obvious complexity in the care of patients in the process of end of life. Actions are permeated by the objectivity of legislation and subjectivity of dealing with death and human frailty. To further explore this theme, the present study aimed to analyze the perception about death and orthothanasia of health professionals of curative and palliative care teams in oncology.

\section{Method}

\subsection{Type of study}

This is a descriptive and exploratory research with a qualitative approach aimed at deepening this theme, still little explored in the literature.

\subsection{Participants}

Based a saturation criterion, we counted on the participation of eight health professionals from a reference center in oncology in Fortaleza (Ceará, Brazil): a physician, a nurse, a social worker and a psychologist of the palliative care team, and an oncologist physician, a nurse, a social worker and a psychologist of the curative care team.

\subsection{Instruments and Techniques}

Three instruments were used in two distinct stages. For the accomplishment of Stage 1, a script of semi-structured interview was used. The script contained the 
following categories: (1) understanding about cancer and the orthothanasia; (2) professional-family-patient relationships; (3) the team's perception of the death process of cancer patients; and (4) the experiences and learning with cancer.

In order to complement the information collected in the interview and to obtain a greater richness of data, two other instruments were used in a Stage 2. The Free Word Association Test (WAT) was used, where the inducers "cancer" and "orthothanasia" were used for participants to mention 5 words for each. It is recognized that although this technique is widely used in studies based on the theory of Social Representations and in quantitative research, a license was requested for its use as a complementary tool to analyze the interviews.

In addition, a Photo Projection Test (PPT) was created, where 5 images selected on the Internet were shown: (1) A hospitalized woman sitting in an armchair, with only an access in the hand, taking care of a baby; (2) Sedated and intubated elderly patient in an ICU, with several devices around him; (3) Bedridden person, at home, without devices, receiving support from health professionals; (4) A woman with no hair, with a nasal catheter (for breathing), bedridden, at home, being cared by the companion; and (5) Young patient in an apartment in the hospital, using enteral catheter (for feeding), being visited by relatives and a dog. The participants were then asked to indicate the stimulus-image that best represented the word "cancer" and "orthothanasia", the same inducing stimulus used in the WAT. Finally, the interrelation of significance of each image in the context of the hospital triad professionalpatient-family was problematized. It is contemplated that the criterion of selection of images was based on the sense, meaning and utility attributed to them socially and technically on what is cancer and orthothanasia, and that would promote creative self-perception in a personal and professional setting.

By means of these three instruments, we intended to answer the central question of the research: "What is the perception of health professionals about death and orthothanasia?". What was asked necessarily goes through the complexity of the question under analysis, in what concerns to understand what they think, represent and communicate when experiencing this process.

\subsection{Ethical Procedures and Data Collection}

After authorization of the research by Ethics Committee, through Opinion $\mathrm{n}^{\mathrm{o}}$ $2,036,680$, the professionals were contacted and data was individually collected with the aid of a recorder and a tablet, at places and times chosen by them, in two different moments: Stage 1 - interviews with the help of the semi-structured script; and Stage 2 - WAT and PPT application. All ethical aspects regarding research involving human beings proposed by Resolutions 466/12 and 510/16 of the Brazilian Health Council, were considered.

\section{Data analysis}

Data were evaluated in four stages: analysis of the interviews, of the WAT, the PPT and, in the end, a triangulation of the results. The interviews with the professionals were analyzed using the Iramuteq software (Interface for Multidimensional Analyzes of Textes et de Questionnaires). Classical lexicographic analyses were performed to 
verify the statistics of the amount of evocations and forms. Descending Hierarchical Classification (DHC) was applied for recognition of the dendogram with the classes that appeared, disregarding the words with $\mathrm{x} 2<3.80(\mathrm{p}<0.05)$. Factorial Correspondence Analysis (FCA) was used for the verification of the differences in the discourses before the sociodemographic data; and the Word Cloud, in order to group the words and organize them graphically according to their frequency ${ }^{(28)}$.

For the analysis of WAT, the blocks of words were considered separately for each inducing stimulus, i.e. "Cancer" and "Orthothanasia". The words of each stimulus were analyzed and frequencies were estimated. Afterwards, they were submitted to the technique of word reduction and understood through simple frequency analysis. Finally, the frequencies were estimated for the PPT, followed by the analysis of meanings. At the end, a dialogue was held between the results of the three instruments.

\section{Results}

This topic refers to the analyses carried out with the objective of understanding the perception about dignified death and orthothanasia of health professionals of curative and palliative care teams in oncology. Data analyses are presented in four parts: (1) interviews with professionals; (2) Free Word Association Test - WAT; (3) Photo Projection Test - PPT; and (4) Triangulation of results.

\section{A. Interviews with Professionals}

The textual statistics showed that the general corpus consisted of 602 text segments (TS), using 517 TSs $(85.88 \%$ ). There were 20,966 occurrences (words, forms or words), with 2,487 different words and 1,269 presenting a single occurrence. From the descending hierarchical classification (DHC), the analyzed content was categorized into five classes: Class 1 - "Transition from curative care to exclusive palliative care: acceptance of prognosis", with 124 TSs (23.98\%), Class 2 - "Acceptance of death" with 71 TS (13.73\%), Class 3 - "Exclusive palliative care practices", with 122 TSs $(23.60 \%)$, Class 4 - "Interdisciplinary teamwork", with 94 TSs (18.18\%); and Class 5 - "The family in the context of dignified death: its importance and illness", with 106 TSs $(20.50 \%)$.

Class 1 - "Transition from curative care to exclusive palliative care: acceptance of prognosis" - accounted for $23.98 \%$ of text segments ( $\mathrm{f}=124 \mathrm{TSs}$ ). It consisted of words such as "Treatment" $\left(x^{2}>35.93\right)$; "Relationship" $\left(x^{2}>33.68\right)$; "Cancer" $\left(x^{2}>19.48\right)$; "Healing" $\left(\mathrm{x}^{2}>14.83\right)$; "Clarifying" $\left(\mathrm{x}^{2}>12.78\right)$; "Oncologic" $\left(\mathrm{x}^{2}>9.56\right)$; "Hope" $\left(\mathrm{x}^{2}>8.76\right)$; "Disease" $\left(\mathrm{x}^{2}>6.71\right)$; "Caring" $\left(\mathrm{x}^{2}>6.52\right)$ and "Patient" $\left(\mathrm{x}^{2}>5.84\right)$.

The content of this class portrays the process of acceptance of the prognosis of chronic cancer by the patient; the need to change the therapeutic approach, by suspending curative care and using exclusive palliative care; and the meaning of these processes for health professionals. For this experience to be positive for patients, families and professionals, communication and clarification to patients about the transition from curative treatment to the exclusive palliative phase is evidently important in this class. For this, the communication needs to be based on compassion, empathy and caution, showing to the sick persons that he will not be abandoned; the only change is in the focus of the intervention. 
Figure 1. Dendogram of descending hierarchical classifications.

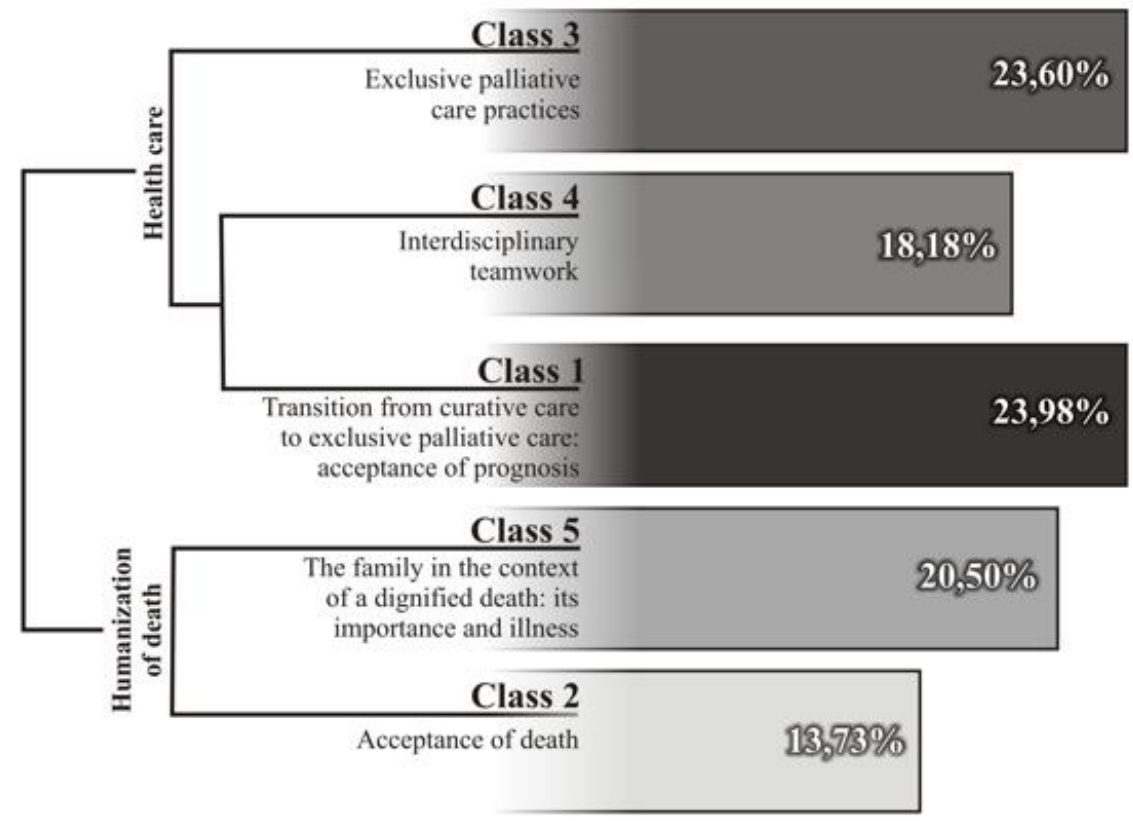

Sometimes healing is not always possible, especially if it is a chronic disease, but then we come with the possibility of caring, we can provide care until the last moment (Individual 5).

Class 2 - "Acceptance of death" - comprises $13.73 \%$ ( $\mathrm{f}=71 \mathrm{TSs}$ ) of the total corpus analyzed. Among its words, the following stood out: "To need" $\left(\mathrm{x}^{2}>49.84\right)$; "Subject" $\left(\mathrm{x}^{2}>44.95\right)$; "To support" $\left(\mathrm{x}^{2}>31.72\right)$; "Orthothanasia" $\left(\mathrm{x}^{2}>29.06\right)$; "Dignified" $\left(\mathrm{x}^{2}>2\right.$ 29.706); "Procedure" $\left(\mathrm{x}^{2}>25.32\right)$; "Cycle" $\left(\mathrm{x}^{2}>25.32\right)$; "To continue" $\left(x^{2}>24,82\right)$; "Dying" $\left(x^{2}>20.40\right)$ and "Therapeutic" $\left(x^{2}>14.36\right)$.

The content of this class deals mainly with the difficulties and challenges faced by professionals with regard to the diagnosis of illness with no possibility of cure, and the need for their acceptance to receive a good care in the "termination of the life cycle" and decision making on a dignified death. The professionals also project in the process of acceptance of death by the patients the meaning of their own finitude, reflecting on teir own terminality and dignity of death.

Because when we talk, the individual cannot sustain a dialogue on dying. 'You're going to die tomorrow'. Or else, you realize that your body is languishing and you are going to die (Individual 4).

Of death as the end of a cycle. We still have to understand that this guy is not ready yet. We're not ready to die. If someone told me that I was going to die today, I would be devastated (Individual 3). 
Class 3 - "Exclusive Palliative Care Practices" - accounted for $23.60 \%$ of text segments ( $f=122$ TSs). It was composed of words like: "Life" $\left(x^{2}>102.68\right)$; "Quality" ( $\left.x^{2}>50.02\right)$; "Sense" $\left(x^{2}>30.36\right)$; "Caution" $\left(x^{2}>28.95\right)$; "Exclusive" $\left(x^{2}>21.66\right)$; "Single" $\left(x^{2}>21.13\right)$; "Palliative" $\left(x^{2}>19.13\right)$; "Death" $\left(x^{2}>16.36\right)$; "Meaning" $\left(\mathrm{x}^{2}>16.35\right)$ and "Contributing" $\left(\mathrm{x}^{2}>16.35\right)$.

This category addresses the perception of professionals of the multiprofessional team about the definition and possibilities of intervention with patients in exclusive palliative care. In this context, the professionals work to contribute to the understanding and significance of the death process of patients. They reinforce that caring involves the effort and dedication of health professionals to promote quality of life and physical, emotional and psychological well-being through control of symptoms, comfort, and active listening to end-of-life patients.

We can control the symptoms, the quality of life, the suffering. So this is a great satisfaction, and today I do my work, I have at least contributed to that suffering, to reduce it (Individual 8).

Class 4 - "Interdisciplinary teamwork" - comprises $18.48 \%$ ( $\mathrm{f}=94 \mathrm{TSs}$ ) of the total corpus analyzed. It consisted of words such as "Professional" $\left(\mathrm{x}^{2}>51.55\right)$; "Psychology" ( $\left.x^{2}>35.83\right)$; "Service" $\left(x^{2}>30.78\right)$; "Institution" ( $\left.x^{2}>30.78\right)$; "To communicate" ( $\left.\mathrm{x}^{2}>18.41\right)$; "Nutrition" ( $\left.\mathrm{x}^{2}>18.14\right)$; "Ambulatory" $\left(\mathrm{x}^{2}>18.14\right)$; "Residence" ( $\left.x^{2}>17.63\right)$; "Physician" $\left(x^{2}>13.00\right)$ and «Hospital» $\left(x^{2}>9.33\right)$.

It presents contents related to the professionals $>$ understanding of the relationships that are built between the members of the interdisciplinary team in the hospital and home context. They emphasized the need of the different sets of knowledge, different professional categories, to provide comprehensive care to patients. Learning, exchange of information about the disease and treatment, establishment of bonds of trust, and the importance of teamwork emerge in this scenario.

It is a very complicated disease, because you see that really the person needs not only medical or only biological support, but the support of a social network; religious support, which is very important; nutrition support. In short, he needs the support from all professionals (Individual 4).

Class 5 - "The family in the context of dignified death: its importance and illness" - accounted for $20.50 \%$ of the text segments ( $f=106 \mathrm{TSs}$ ). It was composed of words like "Child" $\left(\mathrm{x}^{2}>51.71\right)$; "Home" $\left(\mathrm{x}^{2}>48.72\right)$; "To imagine" $\left(\mathrm{x}^{2}>25.92\right)$; "Mother" $\left(x^{2}>23.54\right)$; "Leaving" $\left(x^{2}>19.91\right)$; "Father" $\left(x^{2}>19.58\right)$; "Husband" $\left(x^{2}>19.58\right)$; "Dignity" ( $\left.\mathrm{x}^{2}>18.87\right)$; "Pain" $\left(\mathrm{x}^{2}>16.92\right)$ and "Woman" $\left(\mathrm{x}^{2}>15.63\right)$.

The class has as its central theme the importance of family involvement with cancer patients. From the perception of health professionals, the family has a fundamental importance in the process of dignified death. However, it is noticed that it is also subject to illness from the moment in which the plans change and the routine changes to take care of the patient. Thus, they also need support and care from the multiprofessional team. The interviewees also talk about the desirable home care in terms of dignified death, in home care, highlighting, however, the difficulties of its accomplishment, either for lack of ideal physical structure in the home or for difficulties in the family structure. 
Yesterday we did a very beautiful job with the patient and for me it would be an example of dying with dignity, without suffering, with comfort, with the family, at home. For me, that would be dignity (Individual 1).

We think that dignity is to die at home with family. The family sometimes has no structure to handle it. We have to think about the dignity of those who stay too (Individual 6).

At the end of the analysis of classes through Factorial Correspondence Analysis (FCA), it was possible to make comparisons between evocations by type of professional category and by type of performance/care provided. In the comparison by professional category, we observed that the social workers referred more often to the words "Support", "Social", "Example" and "Work". The nurses referred more to the words "Sedation", "Helping", "Learning", and "Healing". Physicians mentioned more often the words "Hope", "Sense", "Duty", and "Perspective". And finally, psychologists expressed more the words "To imagine", "Subject", "Need" and "Limitation". It is understood that the different professionals highlight words that are the focus of the work they perform.

Then, the word cloud obtained from the participants' speeches was analyzed. The organization and grouping of words according to their frequency made it possible to visualize some central words of the speeches of professionals: "Person", "Patient", "Family", "Life", "Death" and "Care". Words like "know", "Work", "Professional", "Palliative", "Time", "Treatment", "Moment", "Hospital" and "Cancer" were also visualized.

Figure 2. Word cloud obtained from the participants speeches.

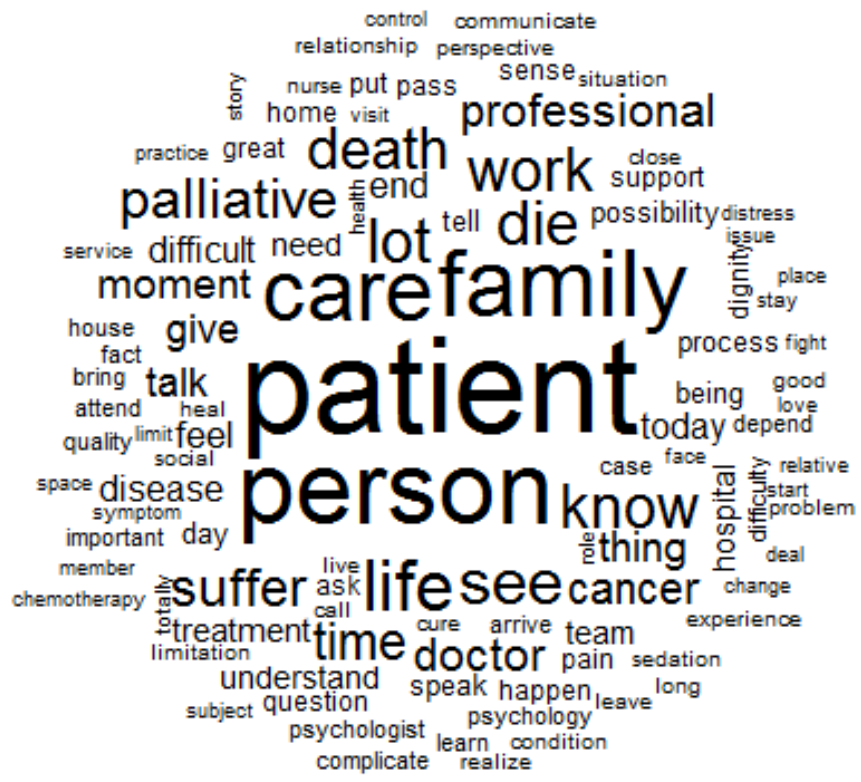




\section{B. Free Word Association Test - WAT}

\section{Inductive stimulus "Cancer"}

From the inductive stimulus "Cancer", 39 evoked words we extracted (one of the subjects evoked only 4 words). These were counted, and the frequency of professionals who evoked each word was: "Suffering" ( $\mid=06 ; 75 \%)$; "Pain" $(\mid=04 ; 50 \%)$; "Death" $\left(\begin{array}{l}\mid \\ \mid\end{array}\right.$ $=01 ; 12.5 \%$ ) (see Table 1$)$. Then, for better apprehension of the results, the evoked words were clustered into categories of synonyms, allowing the identification of the frequency of the represented evocations regardless of the word used. In a synthetic way, "Suffering" and "Death", as well as the ideas of "Overcoming" and "Practices of Humanization" were reinforced as synonyms of cancer.

\section{Inductive stimulus "Orthothanasia"}

From the inductive stimulus "Orthothanasia", 33 words were evoked (one subject evoked only 2 words and another evoked only one). The frequency of professionals who evoked each word was: "Dignity" $(\mid=03 ; 37.5 \%)$; "Death" $(=02 ; 25 \%)$; "Tranquility" ( $\mid=02 ; 25 \%)$; "Relief" $(\mid=02 ; 25 \%)$; and the other recalled words were cited only once $(1=01 ; 12.5 \%)$ (see Table 1$)$. Then, to better apprehend the results, the evoked words were clustered into categories of synonyms, reinforcing as a synonym of orthothanasia the words "Dignity", "Practices of Humanization and Palliative Care".

\section{Photo Projection Test - PPT}

From this test, we obtained the images that best represented "Cancer" and "Orthothanasia", with the justification of choice, before five options of images previously selected by the researchers (see Table 2). The word "Cancer" was predominantly portrayed by the image $4(\mathrm{f}=6 ; 75 \%)$ (Female patient with no hair, with nasal catheter for breathing, bedridden, at home, being cared by the companion). The definition of this image, added to the expression of these lines, shows that health professionals see cancer as a disease marked by the suffering of the patient and the damages caused to the patient's body, including the experience of several losses, such as debilitation, slimming, hair loss, and impairments.

On the other hand, the word "orthothanasia" was represented by three illustrations: image $3(\mathrm{f}=3 ; 37.5 \%)$ - bedridden person, at home, without devices, receiving support from health professionals; image $5(\mathrm{f}=3 ; 37.5 \%)$ - Young patient in an apartment in the hospital, using enteral catheter for feeding, receiving visits from relatives and a dog; and image $4(\mathrm{f}=2 ; 25 \%)$ - A woman with no hair, with a nasal catheter (for breathing), bedridden, at home, being cared by the companion. It can be inferred, from the data seized, that care for these patients should be differentiated, because the death process is a difficult time and professionals must pay special attention to their demands. In this aspect, the importance of caring, embracing, supporting, relieving pain, showing affection and also involving the family during this process stand out. 


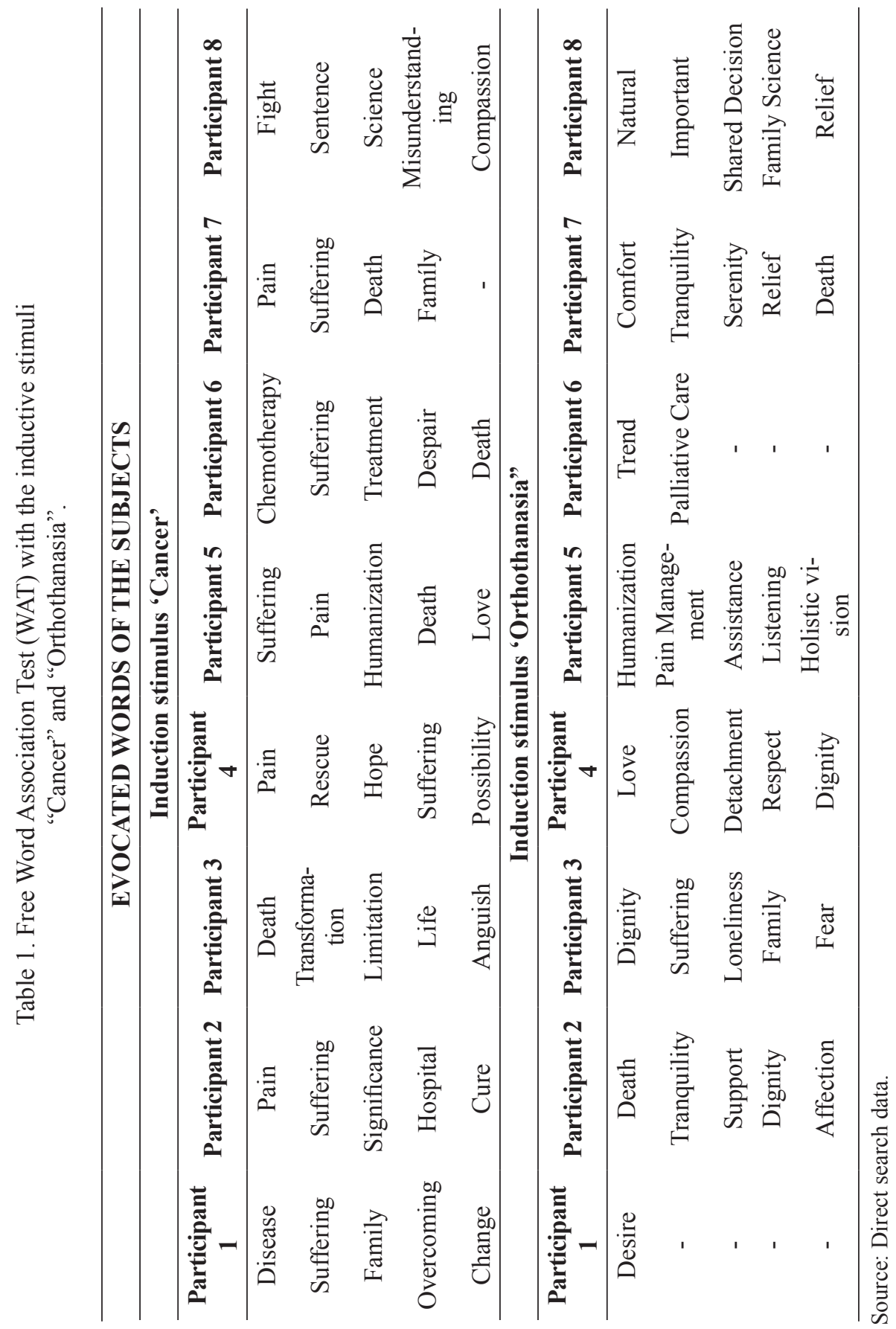


Table 2. Photo Projection Test (PPT) for the words "Cancer" and "Orthothanasia"

\begin{tabular}{|c|c|c|}
\hline \multicolumn{3}{|r|}{ Image representative of "Cancer" } \\
\hline Participant & Image & Justification \\
\hline Indivídual 1 & 4 & $\begin{array}{l}\text { "It is a disease where there is no participation of the patient or } \\
\text { of the family". }\end{array}$ \\
\hline Indivídual 2 & 4 & "By suffering, lack of hair, care, being close to family". \\
\hline Indivídual 3 & 4 & $\begin{array}{l}\text { "Suffering for both the patient and the family and a constant } \\
\text { struggle for life at the same time, a moment of goodbye. Suffering } \\
\text { mixed with embracement, family". }\end{array}$ \\
\hline Indivídual 4 & 4 & "The issue of limitations, hair loss, weight loss." \\
\hline Indivídual 5 & 5 & "Look weakened, emaciated". \\
\hline Indivídual 6 & 2 & $\begin{array}{l}\text { "Attempt to heal many signs and many symptoms through tangles } \\
\text { of wires and machines." }\end{array}$ \\
\hline Indivídual 7 & 4 & "Expression of suffering, of the patient's need". \\
\hline Indivídual 8 & 4 & $\begin{array}{l}\text { "Stigma of the cancer patient, devastated by the disease, with a } \\
\text { close family member showing compassion". }\end{array}$ \\
\hline \multicolumn{3}{|r|}{ Representative image of "Orthothanasia" } \\
\hline Participant & Image & Justification \\
\hline Indivídual 1 & 3 & "Much love, affection and care". \\
\hline Indivídual 2 & 3 & "Surrounded by affection and care". \\
\hline Indivídual 3 & 5 & "By the embracement". \\
\hline Indivídual 4 & 5 & $\begin{array}{l}\text { "It shows the resources, the broader care and the attempt to alle- } \\
\text { viate pain and suffering". }\end{array}$ \\
\hline Indivídual 5 & 3 & "Presence of the family and support at this time". \\
\hline Indivídual 6 & 5 & $\begin{array}{l}\text { "Terminal patient at home being cared for by the family and a } \\
\text { pet". }\end{array}$ \\
\hline Indivídual 7 & 4 & $\begin{array}{l}\text { "The patient is receiving care, it seems to be at home, that would } \\
\text { be ideal." }\end{array}$ \\
\hline Indivídual 8 & 4 & $\begin{array}{l}\text { "The patient is saying good-bye, without devices, with minimal } \\
\text { support to avoid much suffering." }\end{array}$ \\
\hline
\end{tabular}

Source: Direct search data.

\section{Triangulation of Results}

The interviews analyzed through the Iramuteq software organized the material collected in the interviews in five classes: transition from curative care to exclusive palliative care: acceptance of prognosis (Class 1), acceptance of death (Class 2), exclusive palliative care practices (Class 3), interdisciplinary teamwork (Class 4), and the family in the context of dignified death (Class 5). The results indicated that caregivers and palliative care professionals recognize that the diagnosis of a serious illness such as cancer, especially when there is no possibility of cure, is characterized as a complex situation for the patients and their families. The importance of the 
acceptance of the prognosis of death and of the change of therapeutic approach by the whole triad (professionals, patients and families) was considered, presenting palliative care as a form of intervention that aims to relieve the symptoms and to promote dignity of death in an integral way, through an interdisciplinary team, either in the hospital or at home. In addition, the role of the families to support the patient and as a protagonist in home care, the risk of family members to get ill and the importance of care from professionals to the family were reinforced.

The analysis comprised by the Free Word Association Test (WAT) pointed out the perception of the professionals about cancer and orthothanasia. The short form of the evoked words reinforced the perception that they have about cancer as a disease marked by a treatment that generates suffering and pain, and with risk of death. They also confirmed the perception of orthothanasia, such as the practice of palliative care, where care predominates in order to offer dignity of death, as it seeks to reduce the suffering of the patients and their families.

Finally, the Photo Projection Test (PPT) concretized these perceptions in an image. Cancer was represented by the patient who suffers and who is physically "harmed" by the treatment. Orthotanasia is a practice of care, farewell and embracement.

By drawing out a counterpoint, we observed that there was a corroborative interweaving between the results of the three instruments. It was therefore possible to broaden the understanding about the perception that health professionals of the curative and palliative care team in oncology have about death and orthothanasia.

\section{Discussion}

The present research showed that cancer is perceived by the participants as synonymous with suffering, death and pain. These findings are in line with the social representation that this disease has, due to its high mortality rates and the physical and psychological deterioration associated with its treatment, which is marked by weight loss, pain, hair loss and limitation ${ }^{(14)}$. Within this context, orthothanasia is perceived as an approach that offers care, dignity and relief of pain and symptoms ${ }^{(16)}$.

The participants reported that when the cancer progresses to point where there is no expectation of cure, the acceptance of the prognosis and the need to change the therapeutic approach with the use of exclusive palliative care become important. In this regard, the literature emphasizes that the curative and palliative approaches walk side by side, and that palliative measures should not be limited to the final moments of life, but should be applied throughout the treatment process of incurable diseases. When the disease reaches the process of termination, exclusive palliative care remains. Thus, orthothanasia must never be confused with misthanasia. They also reinforce that, given the complexity and severity of the disease, communication becomes a fundamental tool for successful treatment ${ }^{(14-16)}$.

The fluidity of this process and acceptance of changing the care approach also permeates the acceptance of terminality and death. This is because death is still a very difficult event to be faced by human beings, especially when it comes to the perception of the own terminality. It implies an intense emotional exhaustion for 
professionals who work with patients in the process of finitude, who experience losses and the human frailty. It is a unique experience, not only because the experience of each process is unique and surprising, but also because its impact is particular $^{(5-6,29)}$.

As therapeutic possibilities of exclusive palliative care, the professionals can contribute to the patient's understanding and signification of the death process, promoting quality of life and physical, emotional and psychological well-being through control of symptoms, comfort, and listening. In this context, it is possible to see the sensitivity of health professionals to deal with these patients, in order to respect their dignity and control the physical symptoms and suffering, since people suffering from incurable diseases require humanized care, based on bioethical principles that contemplate the ethics of life ${ }^{(16-18)}$.

Care that must be offered by interdisciplinary teams in the hospital and home context, through the integration of different sets of knowledge, so that a comprehensive attention may be provided to the patients. In this respect, the literature states that the multidetermined understanding of the disease process allows the diversified expansion of the team's performance in order to identify the positive and negative factors, relevant to the development of each case. Patients in final stages must be accompanied in an integral way, for this requires interaction of knowledge, sharing of responsibilities, where differentiated problems are solved by a team ${ }^{(17)}$.

Beside these professionals, it is important to involve the families of cancer patients, the caregivers, offering dignity to the patients, but also to the relatives. This is because the family constitutes a support network in which, when an illness affects one of its members, all suffer the consequences. On the basis of this premise, when the relatives see their loved ones close to death, they express the desire to keep the patient under their care, but for this to be possible, it becomes necessary to learn about care and ways of dealing with the suffering and pain of the others. These aspects indicate the importance of making the family a partner in the care of the patient, as well as the inclusion of care in the family. This favors the view of a patient as a singular human being and the understanding that the family also needs to be cared for, since its members are vulnerable and subject to illness ${ }^{(17)}$.

Home care brings the protagonism of the family, with support and care given by the team of professionals. This is a growing proposal in health policies of Latin American countries, justified by high hospital admission costs. It is important to highlight, however, that if, on the one hand, home care can reduce hospital expenses, on the other, it can increase the costs of health care in the family. If, on the one hand, there is a clear intention of the State to reduce care expenses for people with chronic illnesses or those seeking palliative care, on the other hand, there is a clear need for a daily caregiver responsible for the family. Thus, transferring the costs of care to families leads to profound changes in the organization and livelihoods of families, and in many cases, it means giving up paid work. Thus, they increasingly restrict public policy as part of reform decisions that frame the health sector in market thinking, anti-state intervention, and pro-accountability of the family for care ${ }^{(16-17)}$. 


\section{Conclusion}

The purpose of this research was to analyze the perception of dignified death and orthothanasia in the view of health professionals of curative and palliative care teams in oncology. In a complementary way, we wanted to understand how health professionals perceive the death process of end-stage cancer patients.

To discuss the theme of orthothanasia and dignified death with health professionals represents an instrument of understanding and a strategy of action in the hospital and home environment. Such a tool is not restricted only to the technical application of knowledge acquired during the training and qualification process. It also extends to the subjectivity of individuals, aggregating their experiences, beliefs, values, and social knowledge constructed and shared by them in their work routine.

On the basis of the analysis of the results of the three instruments applied consistently, we concluded that the professionals understand that cancer is a disease that causes suffering and a real possibility of death, but that caring goes beyond cure. The health team can do a lot for patients without possibilities of therapeutic cure, such as guaranteeing a painless end of life, controlling the uncomfortable symptoms, keeping the patients conscious and close to their relatives and loved ones. It is not about abbreviating death, or lengthening life, but guarantee dignity until the end. Finally, health professionals recognize the importance of a differentiated and humanized care and, despite all the challenges experienced, they consider the practice of orthothanasia.

Among the limitations of the research, we contemplated the participation of professionals working in only one health institution. The number of professionals was small, and data collection was more transversal. For this reason, we suggest the realization of further studies to identify the perception of professionals who work in other institutions, with a greater breadth of participants, and with longitudinal follow-up.

It should be noted that this work does not end here. On the contrary, it instigates others that aim to contribute to and motivate debates about orthothanasia and dignified death to end-stage cancer patients. It encourages health education practices that clarify the population and professionals on the importance, goals and benefits of the practice of orthothanasia and palliative care.

\section{References}

1. Brandão MCP, Sampaio KCP, Mochizuki AB, Santos VC. Palliative care from nurses to oncological patients. Rev Bras de Saúde Funcional 2017; 1(2), 76. Available in: http:// www.seer-adventista.com.br/ojs/index.php/RBSF/article/view/879/743

2. Silva RS, Campos AER, Pereira A. Caring for the patient in the process of dying at the intensive care unit. Rev da Esc de Enfermagem da USP 2011; 45: 738-44. doi: 10.1590/ S0080-62342011000300027

3. Merhy EE. O ato de cuidar: a alma dos serviços de saúde. Secretaria de Gestão do Trabalho e da Educação na Saúde. VER-SUS Brasil: cadernos de textos. Brasília: Ministério da Saúde 2004;108-37. 
4. Silva CFD, Souza DM, Pedreira LC, Santos MRD, Faustino TN. Perceptions of the multiprofessional team on the implementation of palliative care in intensive care units. Ciênc Saúde Coletiva 2013; 18: 2597-604. doi:10.1590/S1413-81232013000900014

5. Inocenti A, Rodrigues IG, Miasso AI. Experiences and sense of family caregivers of patient in oncology palliative care. Rev Eletrônica Enferm 2009; 11: 858-65.

6. Silva, CG, Cota LI, Vieira RO, Arrazão VD, Cyrino LAR. Terminal diseases, essential knowledge for the health professional. Psicol Argumento 2017; 31(72).

7. Sangy M, Oliveira JA. Mediação de conflitos: possibilidades de humanização para a promoção da saúde. Tecer 2013. doi: 10.15601/1983-7631/rt.v6n11p177-189.

8. Zimmermann C, Swami N, Krzyzanowska M, Leighl N, Rydall A, Rodin G, et al. Perceptions of palliative care among patients with advanced cancer and their caregivers. CMAJ 2016:E217-27. doi: 10.1503/cmaj.151171

9. Carrasco VO. Aspectos bioéticos en la atención de los pacientes de las unidades de cuidados intensivos. Rev Méd La Paz 2015; 21: 61-71.

10. Prado RT, Leite JL, Castro EAB, Silva LJ, Silva ÍR. Uncovering care for patients in the death/dying process and their families. Rev Gaúch de Enferm 2018;39. doi: 10.1590/19831447.2018.2017-0011

11. Silva JAC, Souza LEA, Silva LC, Teixeira RKC. Futility and orthotanasia: medical practces from the perspectve of a private hospital. Rev bioét 2014; 22(2).

12. Monteiro F. Beliefs, values and morals: the philosophical underpinnings of dysthanasia. OJPP 2016; 6:406. doi: 10.4236/ojpp.2016.64037

13. Pessini L. Distanásia: até quando investir sem agredir? Rev Bioét 2009; 4(1).

14. Bomtempo TV. A ortotanásia e o direito de morrer com dignidade: uma análise constitucional. Rev Síntese de Direito de Família 2011; 13: 73-92.

15. Moreira RV. Aspects of orthotanasia applicability. Linkscienceplace: Interdisciplinary Scientific Journal 2017; v. 4, n. 2.

16. Ministério da Saúde. Caderno de Atenção Domiciliar. Secretaria de Atenção à Saúde. Departamento de Atenção Básica 2012; Vol 1, Brasília.

17. Gomes ALZ, Othero MB. Cuidados paliativos. Estudos Avançados 2016; 30:155-66.

18. Instituto de Saúde e Gestão Hospitalar (ISGH). Protocolos ISGH I: Cuidados Paliativos; 2014. Available in http://www.isgh.org.br/intranet/images/Servicos /Protocolos/ isgh protoco_cuidado_paliativo.pdf

19. Gutiérrez M, Roque F, Cruciani A. Percepción de los médicos del hospital universitario universidad abierta interamericana sobre la capacitación en cuidados paliativos en diferentes especialidades y actitudes ante los pacientes con enfermedad terminal. Rev Invest en Educ Méd 2015; 4, Issue 14. doi: 10.1016/S2007-5057(15)30064-8

20. Prandi LR, Hasse DZ, Moraes JÁ. Aspectos Legais e Éticos da Ortotanásia. Rev Científica Conhecimento e Sociedade 2016; v. 1, n. 1.

21. Oliveira TCB, Maranhão TLG, Barroso ML Multiprofessional pediatric oncology palliative care team: a systematic review. Id on Line Rev Psicol 2017; 11:492-530.

22. Conselho Federal de Medicina. Resolução 1805/2006.. D.O.U. 28 de nov. 2006, seção I, p. 169. Brasília, 2006. Available in: http://www.portalmedico.org.br /resoluções /cfm /2006/1805_2006.htm

23. Conselho Federal de Enfermagem. Código de Ética dos Profissionais de Enfermagem, 2007. Available in: http://www.cofen.gov.br/wpcontent/uploads/2012/03/ resolução _ 311_anexo.pdf 
24. Oneti, CF, Barreto DMO, Martins EL. Perception of nursing professionals before the practise of disthanasia and orthothanasia. Enferm Foco 2017; 8;443-8. doi:10.1590/ S0104-11692009000400002.

25. Conselho Federal de Serviço Social. Parâmetros para a Atuação de Assistentes Sociais na Saúde. Brasília, 2010. Available in: http://www.cfess.org.br/arquivos/

26. Conselho Federal de Psicologia. Código de Ética Profissional do Psicólogo, 2005. Available in: https://site.cfp.org.br/wp-content/uploads/2012/07/codigo-de-eticapsicologia -1 .pdf

27. Simão VM, Mioto RCT The palliative care and household in country of Latin America. Saúde em Debate 2016; 40:156-69.

28. Camargo BV, Justo AM. Iramuteq: a free software for analysis of textual data. Temas Psicol 2013; 21:513-8.

29. Kübler Ross E. Sobre a Morte e o Morrer. Martins Fontes: São Paulo, 2008. 